\title{
Association of fever and antipyretic treatment with progressive organ dysfunction in sepsis: Prospective cohort
}

\section{Otoniel Toledo-Salinas, ${ }^{1 *}$ Luis A. Sánchez-Hurtado² and Juan Rodríguez-Silverio ${ }^{3}$}

'Specialty Hospital, Centro Médico Nacional La Raza, Instituto Mexicano del Seguro Social; ${ }^{2}$ Specialty Hospital, Centro Médico Nacional Siglo XXI, Instituto Mexicano del Seguro Social; ${ }^{3}$ Postgraduate Education Section, Higher School of Medicine, Instituto Politécnico Nacional. Mexico City, Mexico

\begin{abstract}
Introduction: Whether fever and antipyretic treatment are related to progression of organ dysfunction (POD) in sepsis is currently not known. Objective: To evaluate the association of fever and antipyretic treatment with POD in sepsis. Methods: Prospective cohort study of patients with sepsis. Maximum axillary temperature ( $T^{\circ}$ Max), antipyretic drugs total dose and daily SOFA score were recorded. POD was defined as an increase $\geq 1$ point on the SOFA score. A multivariate logistic regression model was used to evaluate the studied association. Results: 305 patients were included: 163 were women (53.4\%), with a SOFA score of 8 points (6-11); 130 participants (42.62\%) had $T^{\circ} \mathrm{Max} \geq 38^{\circ} \mathrm{C}$, and 76 (24.9\%), $P O D$. Mortality in patients with fever was $26.2 \%$ vs. $20 \%(p=0.21)$, and with POD, $73.7 \%$ vs. $5.7 \%(p=0.01) . T^{\circ} \mathrm{Max} \geq 39^{\circ} \mathrm{C}$ had an OR of $4.96(95 \%$ $\mathrm{Cl}=1.97-12.47, p=0.01)$; and the use of antipyretics, an OR of 1.04 (95\% Cl: $0.58-1.86, p=0.88)$. Conclusions: An axillary $T^{\circ} M a x \geq 39^{\circ} \mathrm{C}$ is a risk factor for $P O D$ in sepsis. The use of antipyretics was not associated with $P O D$.
\end{abstract}

KEY WORDS: Fever. Antipyretic. Sepsis. Organ dysfunction.

\section{Asociación de la fiebre y el tratamiento antipirético con la progresión de la disfunción orgánica en sepsis: cohorte prospectiva}

\section{Resumen}

Introducción: No se conoce si la fiebre y el tratamiento antipirético se relacionan con progresión de la disfunción orgánica (PDO) en sepsis. Objetivo: Evaluar la asociación de la fiebre y el tratamiento antipirético con la PDO en sepsis. Métodos: Estudio de cohorte prospectiva de pacientes con sepsis. Se registró temperatura axilar máxima ( $T^{\circ}$ máx.), dosis total de fármacos antipiréticos y puntuación diaria de la escala SOFA. La PDO se definió como el incremento de SOFA $\geq 1$ punto. Se utilizó un modelo de regresión logística multivariado para evaluar la asociación estudiada. Resultados: Se incluyeron 305 pacientes: 163 mujeres (53.4\%) con puntuación SOFA de ocho puntos (6-11); 130 participantes (42.62\%) presentaron $T^{\circ}$ máx. $\geq 38{ }^{\circ} \mathrm{C}$ y 76 (24.9\%), PDO. La mortalidad en los pacientes con fiebre fue de $26.2 \%$ versus $20 \%$ sin fiebre $(p=0.21)$ y con PDO, de $73.7 \%$ versus $5.7 \%(p=0.01)$. La $T^{\circ}$ máx. $\geq 39^{\circ} \mathrm{C}$ tuvo $R M=4.96$ (IC $\left.95 \%=1.97-12.47, p=0.01\right)$ y el uso de antipiréticos, $R M=1.04$ (IC $95 \%=0.58-1.86, p=0.88$ ). Conclusiones: $L a T^{\circ}$ máx. axilar $\geq 39^{\circ} \mathrm{C}$ es un factor de riesgo para PDO en sepsis. El uso de antipiréticos no se asoció a PDO.

PALABRAS CLAVE: Fiebre. Antipirético. Sepsis. Disfunción orgánica. 


\section{Introduction}

Sepsis is an organ dysfunction syndrome caused by a dysregulated host response to infection. ${ }^{1}$ At least $6 \%$ of hospitalized patients present with sepsis, and mortality ranges from $26 \%$ to $58 \%{ }^{2}$

Sepsis-associated organ dysfunction is not a single event but a process of continuous organic damage caused by different mechanisms that mutually interact. $^{3}$ Objective evaluation of the degree of organ dysfunction in the patient with sepsis is regularly carried out using the Sequential Organ Failure Assessment (SOFA) score. ${ }^{4}$ An increase in SOFA score, i.e., progression of organ dysfunction (POD), is associated with an increase in mortality. ${ }^{5}$

Fever is defined as the presence of an axillary body temperature $\geq 38.3^{\circ} \mathrm{C}$ in the critically ill patient. ${ }^{6}$ It occurs in $50 \%$ of all admissions to the intensive care unit (ICU), and up to $44 \%$ of patients with sepsis have fever at diagnosis. ${ }^{7}$ The Surviving Sepsis campaign does not provide any recommendations about its treatment or a temperature target. ${ }^{8}$

Fever coexists in equilibrium with inflammatory response as an adjuvant for immune functions of infection eradication. ${ }^{9}$ Fever strict pharmacological treatment causes a reduction in oxygen consumption and an improvement in the state of circulatory shock: ${ }^{10}$ however, it could reduce immune ability and have adverse effects in patients with some degree of organ dysfunction. ${ }^{11,12}$ There are two positions regarding the treatment of fever in patients with sepsis: "suppress" and "let it ride;" the former stance continues to be dogma rather than evidence-based practice. ${ }^{13}$ To respond to clinical uncertainty, we have carried out a study with the main purpose to evaluate the association of fever and antipyretic treatment with $\mathrm{POD}$ in patients with sepsis.

\section{Methods}

An observational, longitudinal, prospective study was carried out from June 2018 to March 2020 in a tertiary care ICU with patients aged $\geq 16$ years diagnosed with sepsis (Sepsis-3), ${ }^{1}$ and who had informed consent available. Patients with refractory septic shock (norepinephrine $>0.5 \mu \mathrm{g} / \mathrm{kg} / \mathrm{min}$, mean blood pressure $<65 \mathrm{mmHg}$ ), in post-cardiopulmonary resuscitation state and neurologically critical patients were excluded; those who died within the first 24 hours of ICU stay were censored (Fig. 1). Axillary temperature was measured hourly with a mercury thermometer.
Patients were grouped according to maximum axillary temperature ( $\mathrm{T}^{\circ}$ max) during ICU stay: $36-37.9^{\circ} \mathrm{C}, 38$ $38.9^{\circ} \mathrm{C}$ and $\geq 39^{\circ} \mathrm{C}$. The SOFA score ${ }^{4}$ and the type of antipyretic received with its dosage were recorded on a daily basis. Fever was defined as $T^{\circ} \max \geq$ $38.3^{\circ} \mathrm{C}$ or $\mathrm{T}^{\circ} \max \geq 38^{\circ} \mathrm{C}$ on at least two measurements. ${ }^{6}$ On the other hand, POD was specified as a SOFA increase $\geq 1$ point at discharge from the unit.

The sample was calculated with an alpha level of 0.05 and $80 \%$ statistical power to detect an odds ratio $(\mathrm{OR}) \geq 2$. To determine variables' type of distribution, Kolmogorov-Smirnov normality test was used. Quantitative variables were analyzed with Student's t-test and Mann-Whitney's U-test according to the type of distribution. Qualitative variables were analyzed with the chi-square test. Univariate and multivariate logistic regression analyses were carried out for $\mathrm{T}^{\circ} \max \geq 39^{\circ} \mathrm{C}$ and antipyretic treatment. Survival analysis was carried out for the $T^{\circ}$ max groups using Kaplan-Meier curves and Cox regression analysis. In all cases, a p-value < 0.05 was considered to be statistically significant.

Data analysis was performed using the SPSS statistical program, version 25.0.

\section{Results}

Data of 1255 patients who were consecutively admitted to the ICU were reviewed, out of whom 305 met the inclusion criteria for analysis (Fig. 1).

Median age was 54 years (38-64), and that of SOFA, ${ }^{4}$ eight points (6-11). Most common infections were of abdominal origin (42\%), and septic shock was present in $75.7 \%$ of cases; $42.6 \%$ of the patients with sepsis had fever during ICU stay. Patients with fever required a larger number of days on mechanical ventilation: eight (4-13) vs. four (2-8), $p=0.01$; more days of vasopressor use: four (1-7) vs. three (1-5), $p=0.01$; more days of ICU stay: 10 (5-14) vs. six (3-10), $p=$ 0.01 ; and had a higher percentage of mechanical ventilation withdrawal failure: $33.1 \%$ vs. $16.6 \%, p=0.01$. No statistically significant difference was observed in POD: $30 \%$ vs. $21.1 \%, p=0.07$; or in mortality: $26.2 \%$ vs. $20 \%, p=0.21$ (Table 1).

Most common types of organ dysfunction in patients with and without POD were respiratory failure: $98.7 \%$ vs. $98.7 \%, p=0.99$; hemodynamic dysfunction: $76.3 \%$ vs. $72.5 \%, p=0.51$; and kidney failure: $57.9 \%$ vs. $51.1 \%, p=0.30$.

Median $\mathrm{T}^{\circ}$ max of patients with and without POD was $38^{\circ} \mathrm{C}(36.8-38.5)$ vs. $37.5^{\circ} \mathrm{C}(37-38.3), p=0.31$; the percentage of antipyretic drugs that were used was 


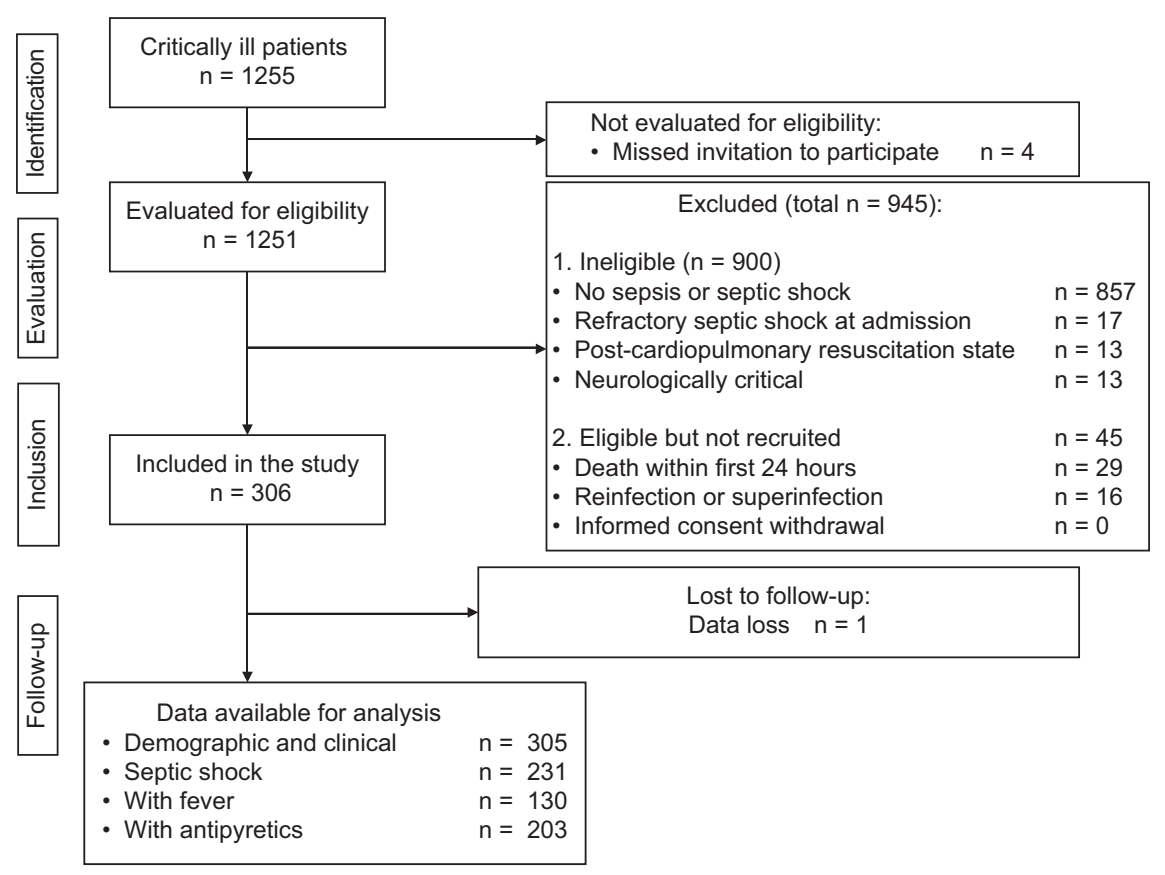

Figure 1. Flowchart describing the research stages.

$51.3 \%$ vs. $45 \%, p=0.33$ (enteral paracetamol: $36.8 \%$ vs. $31 \%, p=0.34$; intravenous metamizole: $43.4 \%$ vs. $31 \%, p=0.04)$. Median enteral paracetamol dose was $1 \mathrm{~g} \mathrm{(0-4)}$ vs. $0 \mathrm{~g}(0-1), \mathrm{p}=0.01$; and that of intravenous metamizole, $3 \mathrm{~g}(2-11)$ vs. $0 \mathrm{~g}(0-1), \mathrm{p}=0.01$.

Patients with POD showed a larger number of days on mechanical ventilation: eight (4-12) vs. five (2-10), $p=0.01$; days with vasopressors: six (4-11) vs. two (1-5), $p=0.01$; and higher mortality: $73.7 \%$ versus $5.7 \%, p=0.01$. The percentage of POD in the group with $\mathrm{T}^{\circ} \max \geq 39^{\circ} \mathrm{C}(8.9 \%)$, and in the group with $\mathrm{T}^{\circ}$ $\max$ of $36-38.9^{\circ} \mathrm{C}(91.1 \%)$ was $51.9 \%$ vs. $22.3 \%, p=$ 0.01 (Fig. 2), whereas mortality was $37 \%$ vs. $21.2 \%$, $p=0.06$. Median number of days on mechanical ventilation for the group with $\mathrm{T}^{\circ} \max \geq 39^{\circ} \mathrm{C}$ was 11 (314) vs. five (3-11), $p=0.18$; median number of days on vasopressors was five (3-10) vs. three (1-6), $p=$ 0.03 ; and median number of days of ICU stay was 12 (4-14) vs. seven (4-12), $p=0.13$.

In the univariate logistic regression analysis, fever had an $\mathrm{OR}=1.59(95 \% \mathrm{Cl}=0.94-2.69, \mathrm{p}=0.07)$, while the group with $\mathrm{T}^{\circ} \max \geq 39^{\circ} \mathrm{C}$ had an $\mathrm{OR}=3.75(95 \%$ Cl: $1.67-8.41, p=0.01)$. Antipyretics administration had an $\mathrm{OR}=1.28(95 \% \mathrm{Cl}=0.76-2.16, \mathrm{p}=0.33)$ : enteral paracetamol showed an $\mathrm{OR}=1.29(95 \% \mathrm{Cl}=0.75-2.23$, $\mathrm{p}=0.34)$, and intravenous metamizole, $\mathrm{OR}=1.71(95 \%$ $\mathrm{Cl}=1.01-2.91, \mathrm{p}=0.04)$, as it can be observed in table 2.

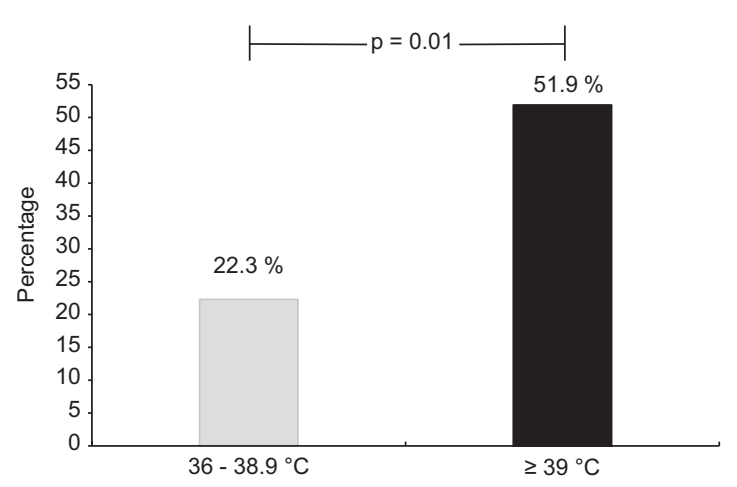

Figure 2. Percentage of organ dysfunction progression at ICU discharge in patients with $T^{\circ} \max 36-38.9^{\circ} \mathrm{C}$ and $\geq 39{ }^{\circ} \mathrm{C}$. $T^{\circ}$ max: maximum axillary temperature during ICU stay; ICU: Intensive Care Unit

In the multivariate logistic regression adjusted for age, an APACHE II ${ }^{14}$ score > 15 points, nosocomial infection, septic shock, antibiotic treatment before ICU admission and use of antipyretics, $\mathrm{T}^{\circ} \max \geq 39^{\circ} \mathrm{C}$ had an $\mathrm{OR}=4.95(95 \% \mathrm{Cl}=1.37-12.47, \mathrm{p}=0.01)$, and antipyretics use, OR $=1.04(95 \% \mathrm{Cl}=0.58-1.86$, $p=0.88)$, as described in table 3 .

Median number of POD-free days was 19 (95\% $\mathrm{Cl}=16-21.99)$, and the log-rank test between the different $T^{\circ}$ max groups did not show statistical significance (Fig. 3). 
Table 1. Demographic and clinical characteristics of patients with sepsis at ICU admission and comparison of patients with and without fever

\begin{tabular}{|c|c|c|c|c|c|c|c|}
\hline \multirow[t]{2}{*}{ Characteristic } & \multicolumn{2}{|c|}{$\begin{array}{l}\text { Sample } \\
n=305\end{array}$} & \multicolumn{2}{|c|}{$\begin{array}{l}\text { With fever } \\
n=130\end{array}$} & \multicolumn{2}{|c|}{$\begin{array}{l}\text { Without fever } \\
\qquad n=175\end{array}$} & \multirow[t]{2}{*}{ p-value } \\
\hline & Median & IQR & Median & IQR & Median & IQR & \\
\hline Age, years & 54 & $38-64$ & 51 & $36-63$ & 57 & $41-66$ & 0.08 \\
\hline Charlson index, score & 1 & $0-2$ & 1 & $0-2$ & 2 & $0-2$ & 0.19 \\
\hline APACHE II, score & 15 & $12-19$ & 15 & $12-19$ & 16 & $11-19$ & 0.66 \\
\hline SOFA, score & 8 & $6-11$ & 9 & $6-11$ & 8 & $5-11$ & 0.88 \\
\hline Mechanical ventilation, days & 5 & 3-11 & 8 & $4-13$ & 4 & $2-8$ & 0.01 \\
\hline Vasopressors, days & 3 & $1-6$ & 4 & $1-7$ & 3 & $1-5$ & 0.01 \\
\hline \multirow[t]{2}{*}{ ICU stay, days } & 7 & $4-12$ & 10 & $5-14$ & 6 & 3-10 & 0.01 \\
\hline & n & $\%$ & n & $\%$ & N & $\%$ & \\
\hline Gender, females & 163 & 53.4 & 58 & 44.6 & 105 & 60 & 0.01 \\
\hline $\begin{array}{l}\text { Comorbidities } \\
\text { Chronic kidney disease } \\
\text { Chronic heart failure } \\
\text { Oncological disorder } \\
\text { Obstructive pulmonary disease } \\
\text { Chronic liver failure }\end{array}$ & $\begin{array}{l}39 \\
27 \\
26 \\
19 \\
14\end{array}$ & $\begin{array}{l}12.8 \\
8.9 \\
8.5 \\
6.2 \\
4.6\end{array}$ & $\begin{array}{l}14 \\
9 \\
7 \\
6 \\
7\end{array}$ & $\begin{array}{l}10.8 \\
6.9 \\
5.4 \\
4.6 \\
5.4\end{array}$ & $\begin{array}{c}25 \\
18 \\
19 \\
13 \\
7\end{array}$ & $\begin{array}{c}14.3 \\
10.3 \\
10.9 \\
7.4 \\
4\end{array}$ & $\begin{array}{l}0.36 \\
0.30 \\
0.09 \\
0.31 \\
0.56\end{array}$ \\
\hline Immunosuppressants & 44 & 14.4 & 17 & 13.1 & 27 & 15.4 & 0.56 \\
\hline Surgical patient & 180 & 59 & 80 & 61.5 & 100 & 57.1 & 0.44 \\
\hline Community-acquired infection & 169 & 55.4 & 67 & 51.5 & 102 & 58.3 & 0.62 \\
\hline $\begin{array}{l}\text { Infection site } \\
\text { Abdominal } \\
\text { Lung } \\
\text { Soft tissue } \\
\text { Urinary }\end{array}$ & $\begin{array}{l}128 \\
106 \\
34 \\
31\end{array}$ & $\begin{array}{c}42 \\
34.8 \\
11.1 \\
10.2\end{array}$ & $\begin{array}{l}52 \\
48 \\
17 \\
11\end{array}$ & $\begin{array}{c}40 \\
36.9 \\
13.1 \\
8.5\end{array}$ & $\begin{array}{l}76 \\
58 \\
17 \\
20\end{array}$ & $\begin{array}{c}43.4 \\
33.1 \\
9.7 \\
11.4\end{array}$ & $\begin{array}{l}0.54 \\
0.49 \\
0.35 \\
0.39\end{array}$ \\
\hline Positive culture & 185 & 60.7 & 81 & 62.3 & 104 & 59.4 & 0.61 \\
\hline $\begin{array}{l}\text { Type of microorganism } \\
\text { Gram-negative } \\
\text { Gram-positive }\end{array}$ & $\begin{array}{c}127 \\
34\end{array}$ & $\begin{array}{l}68.6 \\
18.3\end{array}$ & $\begin{array}{c}59 \\
9\end{array}$ & $\begin{array}{l}72.8 \\
11.1\end{array}$ & $\begin{array}{l}68 \\
25\end{array}$ & $\begin{array}{c}65.3 \\
24\end{array}$ & $\begin{array}{l}0.30 \\
0.02\end{array}$ \\
\hline Septic shock & 231 & 75.7 & 132 & 75.4 & 99 & 76.2 & 0.88 \\
\hline Paracetamol & 99 & 32.5 & 74 & 56.9 & 25 & 14.3 & 0.01 \\
\hline Metamizole & 104 & 34.1 & 98 & 75.4 & 6 & 3.4 & 0.01 \\
\hline Ventilation withdrawal failure & 72 & 23.6 & 43 & 33.1 & 29 & 16.6 & 0.01 \\
\hline Progression of organ dysfunction & 76 & 24.9 & 39 & 30 & 37 & 21.1 & 0.07 \\
\hline Death & 69 & 22.6 & 34 & 26.2 & 35 & 20 & 0.21 \\
\hline
\end{tabular}

APACHE II: Acute Physiology and Chronic Health Evaluation; IQR: interquartile range; SOFA: Sequential Organ Failure Assessment; ICU: intensive care unit.

\section{Discussion}

\section{Key results}

We identified that fever $\geq 39^{\circ} \mathrm{C}$ constitutes a risk factor for POD, while the use of antipyretics did not behave the same way.
The proportion of patients with $\mathrm{T}^{\circ} \max \geq 38^{\circ} \mathrm{C}$ was $42.62 \%$, similar to that reported by Laupland et al..$^{15}(44 \%)$, while Young et al. ${ }^{16}$ identified fever in $20 \%$ of patients with severe sepsis, which differs from our results because the recorded temperature was the daily average of four measurements; however, the reported mortality was $16 \%$, similar to that found in our study (19.3\%). 
Table 2. Univariate analysis of variables associated with progression of organ dysfunction at ICU discharge in patients with sepsis

\begin{tabular}{|c|c|c|c|c|}
\hline Variable & $\beta$ & OR & $95 \% \mathrm{CI}$ & p-value \\
\hline Age $\geq 75$ years & 0.46 & 1.59 & $0.73-3.45$ & 0.24 \\
\hline Charlson index $>2$ points & 0.65 & 1.92 & $1.05-3.51$ & 0.03 \\
\hline Diabetes mellitus & 0.01 & 1.01 & $0.56-1.78$ & 0.98 \\
\hline Chronic liver failure & 0.54 & 1.72 & $0.55-5.31$ & 0.17 \\
\hline Chronic kidney disease & 0.47 & 1.61 & $0.78-3.32$ & 0.19 \\
\hline Immunosuppression & 0.52 & 1.69 & $0.85-3.36$ & 0.13 \\
\hline Cancer & 0.11 & 1.12 & $0.45-2.78$ & 0.81 \\
\hline APACHE II & 0.03 & 1.03 & $0.98-1.08$ & 0.11 \\
\hline SOFA & 0.05 & 1.05 & $0.98-1.14$ & 0.14 \\
\hline Nosocomial infection & -0.65 & 0.52 & $0.30-0.89$ & 0.01 \\
\hline $\begin{array}{l}\text { Antimicrobial treatment } \\
\text { before ICU admission }\end{array}$ & -1.01 & 0.36 & $0.15-0.84$ & 0.01 \\
\hline Positive culture & 0.44 & 1.56 & $0.90-2.71$ & 0.11 \\
\hline Septic shock & 0.04 & 1.04 & $0.56-1.91$ & 0.89 \\
\hline Fever & 0.46 & 1.59 & $0.94-2.69$ & 0.07 \\
\hline $\mathrm{T}^{\circ} \max \geq 39^{\circ} \mathrm{C}$ & 1.32 & 3.75 & $1.67-8.4$ & 0.01 \\
\hline Antipyretics & 0.25 & 1.28 & $0.76-2.16$ & 0.33 \\
\hline Paracetamol & 0.26 & 1.29 & $0.75-2.23$ & 0.34 \\
\hline Metamizole & 0.53 & 1.71 & $1.01-2.91$ & 0.04 \\
\hline
\end{tabular}

Table 3. Multivariate logistic regression analysis of variables associated with progression of organ dysfunction in patients with sepsis

\begin{tabular}{|c|c|c|c|c|}
\hline Variable & $\beta$ & OR & $95 \% \mathrm{Cl}$ & p-value \\
\hline Age $\geq 75$ years & 0.58 & 1.79 & $0.77-4.11$ & 0.17 \\
\hline Charlson index $>2$ points & 0.56 & 1.75 & $0.91-3.35$ & 0.08 \\
\hline Apache II & 0.04 & 1.04 & $0.99-1.10$ & 0.07 \\
\hline Nosocomial infection & -0.51 & 0.59 & $0.33-1.07$ & 0.59 \\
\hline Septic shock & -0.33 & 0.71 & $0.36-1.39$ & 0.32 \\
\hline $\mathrm{T}^{\circ} \max \geq 39^{\circ} \mathrm{C}$ & 1.6 & 4.96 & $1.97-12.47$ & 0.01 \\
\hline $\begin{array}{l}\text { Antibiotic treatment prior to } \\
\text { ICU admission }\end{array}$ & -1.07 & 0.34 & $0.14-0.83$ & 0.01 \\
\hline Antipyretics & 0.04 & 1.04 & $0.58-1.86$ & 0.88 \\
\hline \multicolumn{5}{|c|}{$\begin{array}{l}\text { Chi-square }=30.54 \text {; omnibus test: } p=0.001 ; \text { Nagelkerke's } R^{2}=0.14 \text {. Hosmer-Lemeshow } \\
\text { test: } p=0.18 \text {; global percentage }=74.4 \% \text {; sensitivity }=45 \% \text {; specificity }=76 \% \text {; positive } \\
\text { predictive value }=14 \% \text {; negative predictive value }=94 \% \text {; area under the ROC } \\
\text { curve }=0.71(95 \% \mathrm{Cl}=0.65-0.77 ; p=0.01 \text { ). APACHE: Acute Physiology and Chronic Health } \\
\text { Evaluation; } T^{\circ} \text { max: maximum temperature during ICU stay; ICU: intensive care unit. }\end{array}$} \\
\hline
\end{tabular}

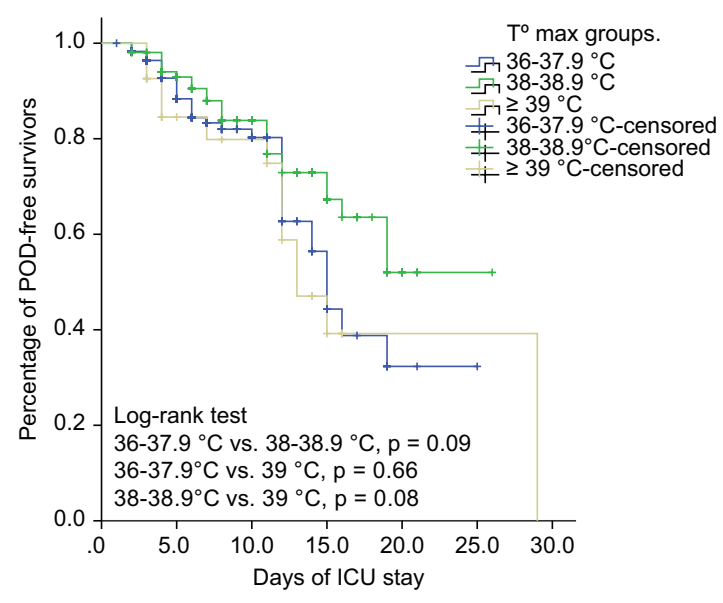

Figure 3. Percentage of $P D O$-free surviving patients by $T^{\circ} \max$ group. PDO: progression of organ dysfunction at ICU discharge; $T^{\circ}$ max: maximum temperature during ICU stay; ICU: Intensive care unit.

To the best of our knowledge, there is no previous analysis in patients with sepsis that has as main purpose assessing the association of fever with $P O D$ (measured using the SOFA 4 scale), a patient-centered outcome that might be of greater clinical importance than mortality. ${ }^{17}$ Ferreira et al. ${ }^{5}$ reported that an increase in organ dysfunction score is related to a poorer outcome, similar to what was found in our study. In turn, Kushimoto et al. ${ }^{18}$ found no difference in mortality between the groups of patients with severe sepsis with a temperature $\leq 36.5^{\circ} \mathrm{C}$ or $>36.5^{\circ} \mathrm{C}(21.5 \%$ vs. $13.4 \% ; p=0.09$ ). At a different temperature (maximum $\geq 38^{\circ} \mathrm{C}$ ), we recorded no difference in mortality or POD either, in comparison with the euthermic group.

\section{Fever and antipyretics as risk factors for $P O D$}

Laupland et al..$^{15}$ reported that patients with a temperature $\geq 39.5^{\circ} \mathrm{C}$ had an $\mathrm{OR}=1.91(1.36-2.7)$, similar to that found in our study. On the other hand, Lee et al., ${ }^{7}$ with exclusion criteria that were similar to those of our investigation, reported that with the definition prior to Sepsis-3, ${ }^{1} \mathrm{~T}^{\circ}$ max from $38.5^{\circ} \mathrm{C}$ to $39.4^{\circ} \mathrm{C}$ was not a risk factor for mortality $(\mathrm{OR}=0.52$; 0.24-1.1; $p=0.09$ ), which contrasts with our finding when we made the comparison with $\mathrm{T}^{\circ} \max \geq 39^{\circ} \mathrm{C}$.

Fujishima et al. ${ }^{19}$ and Paoli et al. ${ }^{20}$ reported that respiratory failure and hemodynamic dysfunction occurred in 40.2 and $29.7 \%$ of patients with sepsis, respectively; in 
our study, respiratory failure and hemodynamic dysfunction were present to a greater extent. The group with POD showed no difference in the proportion that received paracetamol in comparison with the patients without PDO (enteral paracetamol $36.8 \%$ vs. $31 \%$, $p=0.34$ ); however, a larger proportion of the group with POD received intravenous metamizole $(43.4 \%$ vs. $31 \%$; $p=$ 0.04). Notwithstanding, median total dose of each drug did not reach the dosage that, according to the literature, is associated with a higher risk of adverse effects:11,12 enteral paracetamol, $0 \mathrm{~g}$, interquartile range $(\mathrm{IQR})=0-1$ vs. $0 \mathrm{~g}, \mathrm{IQR}=0$-3; $\mathrm{p}=0.31$; intravenous metamizole, $0 \mathrm{~g}$, IQR $=0-1$ vs. $0 \mathrm{~g}, \mathrm{IQR}=0-3 ; p=0.06$. Therefore, the authors attribute this difference to the difficulty in temperature control or to enteral route cancellation (higher clinical severity).

Young et al. ${ }^{21}$ reported that, in patients with suspected severe sepsis, paracetamol was not associated with 28-day mortality in comparison with the placebo group: $\mathrm{RR}=1.00(95 \% \mathrm{Cl}=0.67-1.5 ; \mathrm{p}=0.94)$. Drewry et al. ${ }^{22}$ showed that antipyretic treatment with paracetamol and nonsteroidal anti-inflammatory drugs was not associated with 28-day mortality decrease: experimental results, $\mathrm{I}^{2}=0 \%, \mathrm{OR}=0.93(95 \% \mathrm{Cl}=0.79-1.09)$, and observational results, $\mathrm{I}^{2}=76.1 \%, \mathrm{OR}=0.9(95 \% \mathrm{Cl}=0.54-1.51)$. This is similar to what we found in our study.

\section{$T^{\circ}$ max groups survival}

Lee et al. ${ }^{7}$ and Kushimoto et al. ${ }^{18}$ reported that they found no difference in 28-day mortality between temperature groups: $\geq 39.5^{\circ} \mathrm{C}, 37.5-38.4^{\circ} \mathrm{C}$ and 38.5 $39.4^{\circ} \mathrm{C}$ vs. the reference group: $36.5-37.4^{\circ} \mathrm{C}$. With a different $\mathrm{T}^{\circ}$ max grouping, we did not find a statistically significant difference in POD-free survival either; however, it should be noted that median temperature of the patients who experienced POD (mortality of $73.7 \%$ vs. $5.7 \% ; \mathrm{p}=0.01)$ was $38^{\circ} \mathrm{C}\left(36.8-38.5^{\circ} \mathrm{C}\right)$ vs. $37.5^{\circ} \mathrm{C}\left(37-38.3^{\circ} \mathrm{C} ; \mathrm{p}=0.31\right)$; for this reason, we think that the difference in survival can only be found in the group with a temperature $\geq 39^{\circ} \mathrm{C}$.

\section{Limitations}

First: our design was observational and lacked a standardized method for antipyretic treatment; therefore, the findings can only show POD association and not causality.

Second: patients aged $\geq 75$ years should have been excluded due to changes in the body temperature pattern, and new studies in this age group are therefore suggested. ${ }^{23}$

Third: only the two most widely used antipyretic drugs were included in the analysis; however, all patients received some type of antimicrobial; therefore, we believe that the effect of treatment on PDO might have been diluted in the sample. On the other hand, the use of other nonsteroidal anti-inflammatory drugs was uncommon (the use of opioids was preferred); therefore, their outcome-modifying effect was small. ${ }^{24}$

Fourth: the Infectious Diseases Society of America does not recommend the use of axillary thermometers; however, the use of this method is common due to its non-invasive nature, accessibility, ease of use and low cost in comparison with invasive methods that, in addition, represent a risk factor for the development of nosocomial infections. ${ }^{6}$

Fifth: the role of active non-pharmacological external cooling was not evaluated because the ICU where the research was carried out does not have the necessary devices for its application and monitoring.

\section{Practical implications}

We suggest that, in patients with sepsis and with characteristics similar to those of our population, permissive management of $\mathrm{T}^{\circ} \max 38-38.5^{\circ} \mathrm{C}$ should be carried out, while intensive pharmacological antipyretic management should only be started in patients with $\mathrm{T}^{\circ} \max >38.5^{\circ} \mathrm{C}$

\section{Conclusions}

$\mathrm{T}^{\circ}$ max $\geq 39^{\circ} \mathrm{C}$ during ICU stay is a risk factor for POD in patients with sepsis. In turn, the use of antipyretic drugs in patients with sepsis is not a risk factor for POD.

\section{Acknowledgments}

To Instituto Mexicano del Seguro Social Clinical Research Training Center (CAIC-IMSS).

\section{Conflict of interests}

The authors declare that they have no conflicts of interest.

\section{Funding}

This research did not receive any specific grant from agencies of the public, commercial, or non-profit sectors. 


\section{Ethical disclosures}

Protection of human and animal subjects. The authors declare that the procedures that were carried out adhered to the ethical standards of the responsible committee for experimentation on human beings and were in agreement with the World Medical Association and the Declaration of Helsinki.

Confidentiality of data. The authors declare that they followed the protocols of their work center on the publication of patient data.

Right to privacy and informed consent. The authors obtained informed consent from the patients or subjects referred to in the article; this document is in the possession of the corresponding author.

\section{References}

1. Singer M, Deutschman CS, Seymour CW, Shankar-Hari M, Annane D Bauer M, et al. The Third International Consensus Definitions for Sepsis and Septic Shock (Sepsis-3). JAMA. 2016;315:801-10.

2. Rhee C, Dantes R, Epstein L, Murphy D, Seymour C, Iwashyna T, et al Incidence and trends of sepsis in US hospitals using clinical vs claims data. 2009-2014. JAMA. 2017:318:1241-9.

3. Lelubre C, Vincent JL. Mechanisms and treatment of organ failure in sepsis. Nat Rev Nephrol. 2018;14:417-27.

4. Vincent JL, Moreno R, Takala J, Willatts S, De Mendonça A, Bruining H, et al. The SOFA (sepsis-related organ failure assessment) score to describe organ dysfunction/failure. On behalf of the working group on sepsis-related problems of the European society of intensive care medicine intensive care medicine. Intensive Care Med. 1996:22:707-10.

5. Ferreira FL, Bota DP, Bross A, Mélot C, Vincent JL. Serial evaluation of the SOFA score to predict outcome in critically ill patients. JAMA 2001;286:1754-8.

6. O'Grady NP, Barie PS, Bartlett JG, Bleck T, Carroll K, Kalil AC, et al Guidelines for evaluation of new fever in critically ill adult patients: 2008 update from the American college of critical care medicine and the infectious diseases society of America. Crit Care Med. 2008;36: 1330-49.
7. Lee B, Inui D, Suh G, Kim J, Kwon J, Park J, et al. Association of body temperature and antipyretic treatments with mortality of critically ill patients with and without sepsis: multi-centered prospective observational study. Crit Care. 2012;16:R33.

8. Rhodes A, Evans LE, Alhazzani W, Levy MM, Antonelli M, Ferrer R, et al. Surviving sepsis campaign: international guidelines for management of sepsis and septic shock: 2016. Intensive Care Med. 2017;43: 304-77.

9. Atkins E, Bodel P. Clinical fever: its history, manifestations and pathogenesis. Fed Proc. 1979;38:57-63.

10. Peres-Bota D, Lopes-Ferreira F, Mélot C, Vincent JL. Body temperature alterations in the critically ill. Intensive Care Med. 2004;30:811-6.

11. Chiumello D, Gotti M, Vergani G. Paracetamol in fever in critically ill patients-an update. J Crit Care. 2017;38:245-52

12. Vane JR, Botting RM. Mechanism of action of nonsteroidal anti-inflammatory drugs. Am J Med. 1998;104:2S-8.

13. Ray JJ, Schulman Cl. Fever: suppress or let it ride? J Thorac Dis. 2015;7:E633-6.

14. Knaus WA, Draper EA, Wagner DP, Zimmerman JE. APACHE II: a severity of disease classification system. Crit Care Med. 1985;13:818-29.

15. Laupland KB, Shahpori R, Kirkpatrick AW, Ross T, Gregson DB, Stelfox HT. Occurrence and outcome of fever in critically ill adults. Crit Care Med. 2008;36:1531-5.

16. Young P, Saxena M, Eastwood GM, Bellomo R, Beasley R. Fever and fever management among intensive care patients with known or suspected infection: a multicentre prospective cohort study. Crit Care Resusc. 2011;13:97-102.

17. Dinglas VD, Faraone LN, Needham DM. Understanding patient-important outcomes after critical illness: a synthesis of recent qualitative, empirical, and consensus-related studies. Curr Opin Crit Care. 2018;24:401-9.

18. Kushimoto S, Gando S, Saitoh D, Mayumi T, Ogura H, Fujishima S, et al. The impact of body temperature abnormalities on the disease severity and outcome in patients with severe sepsis: an analysis from a multicenter, prospective survey of severe sepsis. Crit Care. 2013;17: R271.

19. Fujishima S, Gando S, Daizoh S, Kushimoto S, Ogura H, Mayumi T, et al. Infection site is predictive of outcome in acute lung injury associated with severe sepsis and septic shock. Respirology. 2016;21 :898-904.

20. Paoli CJ, Reynolds MA, Sinha M, Gitlin M, Crouser E. Epidemiology and costs of sepsis in the United States-an analysis based on timing of diagnosis and severity level. Crit Care Med. 2018;46:1889-97.

21. Young $P$, Saxena M, Beasley $R$. Acetaminophen for fever in critically ill patients with suspected infection. N Engl J Med. 2016;374:1292-3.

22. Drewry AM, Ablordeppey EA, Murray ET, Stoll CR, Izadi SR, Dalton CM, et al. Antipyretic therapy in critically ill septic patients: a systematic review and meta-analysis. Crit Care Med. 2017:45:806-13.

23. Norman DC. Fever in the elderly. Clin Infect Dis. 2000;31:148-51.

24. Fareed A, Scheinberg K, Gale R, Stout S, Vayalapalli, S, Drexler K. Effect of Buprenorphine on liver function tests for patients undergoing long-term maintenance treatment. Addict Disord Their Treat. 2014;13:133-7. 